\title{
Amorphous gallium oxide grown by low-temperature PECVD
}

Eiji Kobayashi, Mathieu Boccard, Quentin Jeangros, Nathan Rodkey, Daniel Vresilovic, Aïcha Hessler-Wyser, Max Döbeli, Daniel Franta, Stefaan De Wolf, Monica Morales-Masis, and Christophe Ballif

Citation: Journal of Vacuum Science \& Technology A 36, 021518 (2018); doi: 10.1116/1.5018800

View online: https://doi.org/10.1116/1.5018800

View Table of Contents: http://avs.scitation.org/toc/jva/36/2

Published by the American Vacuum Society

\section{Articles you may be interested in}

A review of $\mathrm{Ga}_{2} \mathrm{O}_{3}$ materials, processing, and devices

Applied Physics Reviews 5, 011301 (2018); 10.1063/1.5006941

Guest Editorial: The dawn of gallium oxide microelectronics

Applied Physics Letters 112, 060401 (2018); 10.1063/1.5017845

$1-\mathrm{kV}$ vertical $\mathrm{Ga}_{2} \mathrm{O}_{3}$ field-plated Schottky barrier diodes

Applied Physics Letters 110, 103506 (2017); 10.1063/1.4977857

Enhancement-mode $\mathrm{Ga}_{2} \mathrm{O}_{3}$ wrap-gate fin field-effect transistors on native (100) $\beta$ - $\mathrm{Ga}_{2} \mathrm{O}_{3}$ substrate with high breakdown voltage

Applied Physics Letters 109, 213501 (2016); 10.1063/1.4967931

High breakdown electric field in $\beta-\mathrm{Ga}_{2} \mathrm{O}_{3} /$ graphene vertical barristor heterostructure

Applied Physics Letters 112, 032101 (2018); 10.1063/1.5002138

On the feasibility of p-type $\mathrm{Ga}_{2} \mathrm{O}_{3}$

Applied Physics Letters 112, 032108 (2018); 10.1063/1.5009423

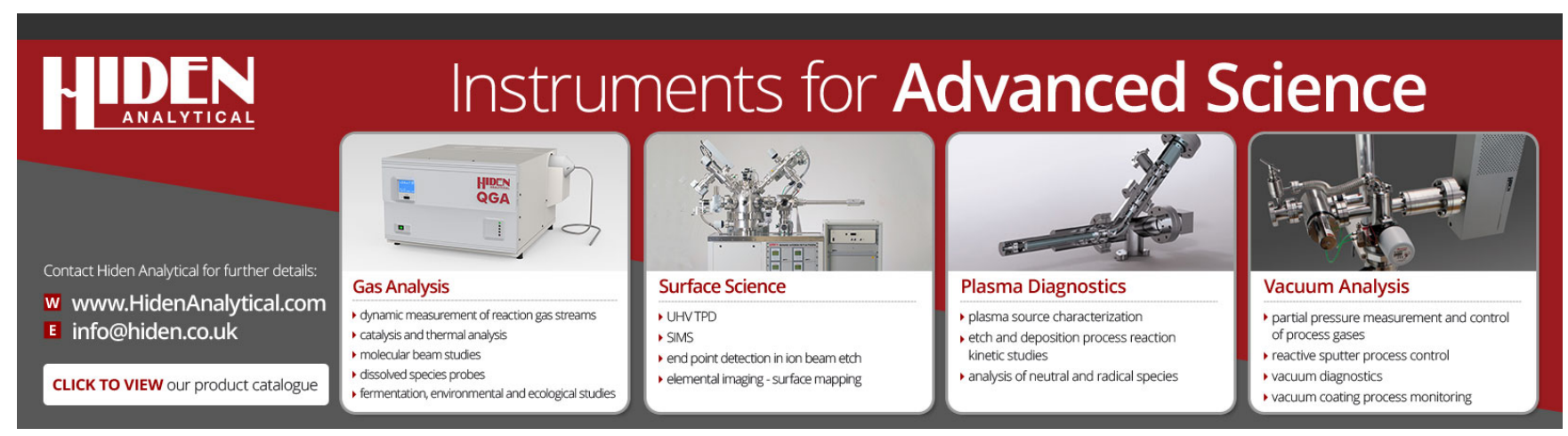




\title{
Amorphous gallium oxide grown by low-temperature PECVD
}

\author{
Eiji Kobayashi \\ École Polytechnique Fédérale de Lausanne (EPFL), Institute of Microengineering (IMT), Photovoltaics \\ and Thin Film Electronics Laboratory, Rue de la Maladière 71b, CH-2002 Neuchâtel, Switzerland; \\ Choshu Industry Co., Ltd., 3740, Shin-yamanoi, Sanyo Onoda, Yamaguchi 757-8511, Japan; \\ and Department of Materials Science and Engineering, Yamaguchi University, 2-16-1 Tokiwadai, \\ Ube, Yamaguchi 755-8611, Japan
}

Mathieu Boccard

École Polytechnique Fédérale de Lausanne (EPFL), Institute of Microengineering (IMT), Photovoltaics and Thin Film Electronics Laboratory, Rue de la Maladière 71b, CH-2002 Neuchâtel, Switzerland

\begin{abstract}
Quentin Jeangros
École Polytechnique Fédérale de Lausanne (EPFL), Institute of Microengineering (IMT), Photovoltaics and Thin Film Electronics Laboratory, Rue de la Maladière 71b, CH-2002 Neuchâtel, Switzerland and Department of Physics, University of Basel, Klingelbergstrasse 82, CH-4056 Basel, Switzerland
\end{abstract}

Nathan Rodkey, Daniel Vresilovic, and Aïcha Hessler-Wyser

École Polytechnique Fédérale de Lausanne (EPFL), Institute of Microengineering (IMT), Photovoltaics and Thin Film Electronics Laboratory, Rue de la Maladière 71b, CH-2002 Neuchâtel, Switzerland

Max Döbeli

ETH Zurich, Ion Beam Physics, Otto-Stern-Weg 5, Zurich 8093, Switzerland

Daniel Franta

Department of Physical Electronics, Faculty of Science, Masaryk University, Kotlářská, 2, Brno 61137, Czechia

Stefaan De Wolf

KAUST Solar Center (KSC), King Abdullah University of Science and Technology (KAUST),

Thuwal 23955-6900, Saudi Arabia

Monica Morales-Masis ${ }^{\text {a) }}$ and Christophe Ballif

École Polytechnique Fédérale de Lausanne (EPFL), Institute of Microengineering (IMT), Photovoltaics and Thin Film Electronics Laboratory, Rue de la Maladière 71b, CH-2002 Neuchâtel, Switzerland

(Received 9 December 2017; accepted 12 February 2018; published 2 March 2018)

Owing to the wide application of metal oxides in energy conversion devices, the fabrication of these oxides using conventional, damage-free, and upscalable techniques is of critical importance in the optoelectronics community. Here, the authors demonstrate the growth of hydrogenated amorphous gallium oxide $\left(a-\mathrm{GaO}_{\mathrm{x}}: \mathrm{H}\right)$ thin-films by plasma-enhanced chemical vapor deposition (PECVD) at temperatures below $200^{\circ} \mathrm{C}$. In this way, conformal films are deposited at high deposition rates, achieving high broadband transparency, wide band gap $(3.5-4 \mathrm{eV})$, and low refractive index $(1.6$ at $500 \mathrm{~nm})$. The authors link this low refractive index to the presence of nanoscale voids enclosing $\mathrm{H}_{2}$, as indicated by electron energy-loss spectroscopy. This work opens the path for further metal-oxide developments by low-temperature, scalable and damage-free PECVD processes. Published by the AVS. https://doi.org/10.1116/1.5018800

\section{INTRODUCTION}

Gallium oxide $\left(\mathrm{Ga}_{2} \mathrm{O}_{3}\right)$ is a wide band gap semiconductor with several crystalline phases; the most stable polymorph is the $\beta$ structure, which has a band gap $\left(E_{g}\right)$ of 4.5 to $4.9 \mathrm{eV},{ }^{1-3}$ the second largest $E_{g}$ for semiconductors after diamond. ${ }^{4}$ If nonstoichiometric, this phase is conductive with an electron mobility at $300 \mathrm{~K}$ up to $150 \mathrm{~cm}^{2} \mathrm{~V}^{-1} \mathrm{~s}^{-1} \cdot{ }^{5-8} \beta$ $\mathrm{Ga}_{2} \mathrm{O}_{3}$ has potential applications as UV transparent electrodes $^{9}$ and field-effect transistors. ${ }^{10,11}$ Recently, amorphous gallium oxide $\left(a-\mathrm{GaO}_{\mathrm{x}}\right)$ with an $E_{g}$ around $4 \mathrm{eV}$ (Ref. 12) has drawn increased attention and was proposed as a transparent electron transport layer in $\mathrm{Cu}(\mathrm{In}, \mathrm{Ga}) \mathrm{Se}_{2}$ (Ref. 13) and

${ }^{a)}$ Electronic mail: monica.moralesmasis@epfl.ch in $\mathrm{Cu}_{2} \mathrm{O}$ (Ref. 14) solar cells as well as a passivation layer for c-Si solar cells. ${ }^{15}$

$\beta$ - $\mathrm{Ga}_{2} \mathrm{O}_{3}$ can be deposited by several methods, including molecular beam epitaxy ${ }^{16-18}$ and metal-organic chemical vapor deposition. ${ }^{19-23}$ In all cases, high temperatures around $900-1050{ }^{\circ} \mathrm{C}$ are needed to obtain high-quality $\beta-\mathrm{Ga}_{2} \mathrm{O}_{3}$ thin films, limiting the choice of substrate. Gallium oxide can also be deposited at lower temperatures using plasma-enhanced atomic-layer deposition (PE-ALD), ${ }^{24}$ yielding poorer crystalline quality or amorphous films. Notably, the growth of $a-\mathrm{GaO}_{\mathrm{x}}$ thin films was achieved by PE-ALD at temperatures in the range of $170-250{ }^{\circ} \mathrm{C}$ using trimethylgallium (TMG) and ozone $\left(\mathrm{O}_{3}\right)$ as reactants, with limited deposition rates though. ${ }^{25,26}$

Here, we demonstrate the use of plasma-enhanced chemical vapor deposition (PECVD) to grow $a-\mathrm{GaO}_{\mathrm{x}}$ using metalorganic precursors as an alternative, scalable approach to 
these techniques. Compared to ALD, PECVD is a suitable method for mass production, with high deposition rates and scalability up to several square meters or even roll-to-roll. PECVD is industrially widespread, notably to manufacture amorphous silicon solar cells ${ }^{27}$ passivating layers in Si heterojunction (SHJ) solar cells, ${ }^{28-34}$ and thin-film transistors of flat panel displays. ${ }^{35}$ Importantly, PECVD tools developed for other types of layers are also suitable to fabricate $\mathrm{GaO}_{x}$ films. We demonstrate that transparent $a-\mathrm{GaO}_{\mathrm{x}}$ films can be deposited by this method at a temperature of $200^{\circ} \mathrm{C}$. The optical properties, microstructure, surface morphology, and composition of the layers are studied, followed by testing this film as an antireflective coating (ARC) in SHJ solar cell.

\section{EXPERIMENTAL SECTION}

Substoichiometric hydrogenated $a-\mathrm{GaO}_{\mathrm{x}} \quad\left(a-\mathrm{GaO}_{\mathrm{x}}: \mathrm{H}\right)$ films were deposited by PECVD using TMG as Ga precursor and carbon dioxide $\left(\mathrm{CO}_{2}\right)$ as oxidant in a custom-built PECVD reactor (originally designed for thin-film silicon deposition) operated at $70 \mathrm{MHz}, 0.4 \mathrm{mbar}$, and $200^{\circ} \mathrm{C}$. A possible reaction between TMG and $\mathrm{CO}_{2}$ is described as follows:

$$
\begin{aligned}
2\left[\mathrm{Ga}\left(\mathrm{CH}_{3}\right)_{3}\right]_{(\mathrm{g})}+3\left[\mathrm{CO}_{2}\right]_{(\mathrm{g})} \rightarrow & {\left[\mathrm{Ga}_{2} \mathrm{O}_{3}\right]_{(\mathrm{s})}+3[\mathrm{CO}]_{(\mathrm{g})} } \\
& +3\left[\mathrm{C}_{2} \mathrm{H}_{6}\right]_{(\mathrm{g})} .
\end{aligned}
$$

The oxidant $\left(\mathrm{CO}_{2}\right)$ gas flow to total gas flow ratio, $Q_{\mathrm{O}}$, was set to be in the range of $93 \%-96 \%$, with $Q_{\mathrm{O}}$ defined as

$$
Q_{O}=\frac{\mathrm{CO}_{2} \text { gas flow }}{\mathrm{CO}_{2} \text { gas flow }+ \text { TMG gas flow }} \text {. }
$$

The film thickness was varied between 2 and $800 \mathrm{~nm}$ depending on specific experimental or characterization method needs. The power-density of the plasma was $40 \mathrm{~mW} / \mathrm{cm}^{2}$, resulting in a deposition rate ranging from 0.7 to $1.1 \mathrm{~nm} / \mathrm{s}$ for $Q_{\mathrm{O}}$ variations between $93 \%$ and $96 \%$, respectively. For all investigated $Q_{\mathrm{O}}$, all $\mathrm{GaO}_{\mathrm{x}}$ films presented an amorphous microstructure as confirmed by X-ray diffraction (D2 PHASER, Bruker, data shown in supplementary material ${ }^{61}$ ).

The refractive indices $(n)$ and extinction coefficients $(k)$ of $a-\mathrm{GaO}_{\mathrm{x}}: \mathrm{H}$ films were determined with variable-angle spectroscopic ellipsometry measurements using a UVISEL ellipsometer (iHR320, HORIBA). ${ }^{36}$ Photothermal deflection spectroscopy (PDS) with a custom-built system was used to determine the $E_{g}$ and the absorption edge of the $a-\mathrm{GaO}_{\mathrm{x}}: \mathrm{H}$ films. ${ }^{37,38}$ We used 800-nm-thick $a-\mathrm{GaO}_{\mathrm{x}}: \mathrm{H}$ films deposited on fused silica to maximize PDS signal and avoid glass absorption. Transmittance and absorptance spectra were measured with a spectrometer (Lambda 900, Perkin Elmer).

The conformality and microstructure of $50 \mathrm{~nm}$-thick layers of $a-\mathrm{GaO}_{\mathrm{x}}: \mathrm{H}$ was assessed by transmission electron microscopy (TEM). Cross-sections of the layer stack were prepared using the conventional focused ion beam lift-out method (sample prepared in a Zeiss NVision) after these have been protected with evaporated carbon and sputtered $\mathrm{Au}$ to prevent FIB-induced damages. The TEM analysis involved the acquisition of STEM high-angle annular darkfield (HAADF) images that were combined with energydispersive X-ray spectroscopy (EDX) to assess the chemistry of the layers (in a FEI Tecnai Osiris microscope operated at $200 \mathrm{kV}$ ). In addition, $\mathrm{GaO}_{\mathrm{x}}: \mathrm{H}$ films with a thickness of $30 \mathrm{~nm}$ were deposited directly onto electron transparent 10 $\mathrm{nm}$-thick SiN windows that were coated with $5 \mathrm{~nm}$ of $\mathrm{C}$ on their backside to prevent charging under the electron beam. Top view STEM dark-field (DF) images, electron energyloss (EEL), and EDX spectra were acquired simultaneously to assess the composition of the film (using convergence and EELS collection semiangles of 28 and $48 \mathrm{mrad}$, respectively, in a FEI TITAN Themis at $80 \mathrm{kV}$ ). Additionally, the composition was assessed by Rutherford backscattering spectrometry (RBS) and by elastic recoil detection analysis (ERDA) as described in supplementary material. ${ }^{39}$ The surface morphology was characterized by atomic force microscopy (AFM; Dimension Edge Scanasyst, Bruker).

Standard silicon heterojunction (SHJ) solar cells were fabricated using $a-\mathrm{GaO}_{\mathrm{x}}: \mathrm{H}$ as a second antireflecting (AR) layer to evaluate its effect in the optical performance of the solar cells (the conventional SHJ design uses a transparent conductive oxide, e.g., tin doped indium oxide (ITO), as the first AR layer). ${ }^{40-43}$ Details on the SHJ cells fabrication can be found in Ref. 44. The $a-\mathrm{GaO}_{\mathrm{x}}: \mathrm{H}$ was deposited on such metalized devices using a shadow mask, covering the front-side ITO and metal fingers. A reference SHJ solar cell was fabricated with a thermally evaporated $\mathrm{MgF}_{2} \mathrm{ARC}$. $\mathrm{MgF}_{2}$ has been successfully applied as AR coating ${ }^{45}$ in several record devices. $^{46,47}$ The current-voltage characteristics of these $4-\mathrm{cm}^{2}$ devices were measured under $1 \mathrm{~kW} / \mathrm{m}^{2}$ AM $1.5 \mathrm{G}$ illumination and their spectral response with a custom-built setup.

\section{RESULTS AND DISCUSSION}

Figure 1(a) shows the transmittance and reflectance spectra of the $a-\mathrm{GaO}_{\mathrm{x}}: \mathrm{H}$ films deposited on fused silica, from which internal transmittance and absorptance are calculated and shown in Fig. 1(b), indicating that these films are transparent from the near UV to the near IR. This is confirmed by the low absorption coefficient $(\alpha)$ values measured by PDS. The $\alpha$ spectra of $a-\mathrm{GaO}_{\mathrm{x}}: \mathrm{H}$ films with $Q_{\mathrm{O}}$ from $93 \%$ to $96 \%$ are shown in Fig. 2(a). $\alpha$ is very low and decreases with increasing $Q_{\mathrm{O}}$. $E_{g}$ was extracted following the Tauc relation $\alpha=\left(h v-E_{g}\right)^{x}$, with $h v$ the photon energy and $x=1 / 2$, assuming direct optical transitions. ${ }^{13,48} E_{g}$ varies from 3.5 to $4.1 \mathrm{eV}$ when $Q_{\mathrm{O}}$ changes from $93 \%$ to $96 \%$ [Fig. 2(c)], indicating that $E_{g}$ can be controlled by the oxidant gas flow during the deposition. Overall, the observed $E_{g}$ of $a-\mathrm{GaO}_{\mathrm{x}}: \mathrm{H}$ is slightly lower than that of $\beta-\mathrm{Ga}_{2} \mathrm{O}_{3}(4.5-5.0 \mathrm{eV}){ }^{1-3}$

Figure 3 shows $n$ and $k$ of $a-\mathrm{GaO}_{\mathrm{x}}: \mathrm{H}$ with $Q_{O}$ from $93 \%$ to $96 \%$ obtained by ellipsometry using a universal dispersion model $^{49}$ (experimental spectra and fits are displayed in Fig. B. 1 of the supplementary material). The static values of the dielectric function (relative permittivity, corresponding to only the electronic part of the dielectric response) of the $a$ $\mathrm{GaO}_{\mathrm{x}}: \mathrm{H}$ films with $Q_{\mathrm{O}}$ of $93 \%, 94 \%, 95 \%$, and $96 \%$ were determined as $2.49,2.42,2.39$, and 2.37 , respectively. $E_{g}$ 

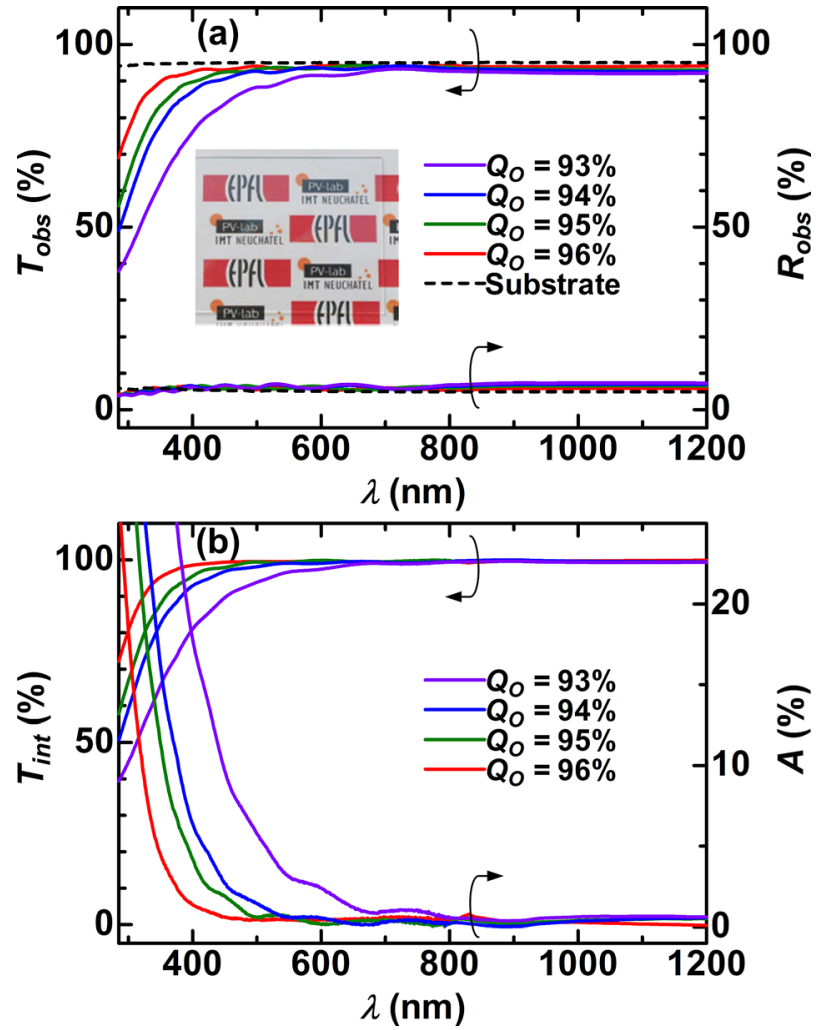

FIG. 1. (Color online) (a) Measured transmittance and reflectance spectra of $a-\mathrm{GaO}_{\mathrm{x}}: \mathrm{H}$ thin films with $\mathrm{CO}_{2}$ gas to total flow ratios $\left(Q_{O}\right)$ of $93 \%, 94 \%$, $95 \%$, and $96 \%$ ( $800 \mathrm{~nm}$ thickness on fused silica substrates). (b) Internal optical transmittance $\left(T_{\text {int }}\right)$ and absorptance $(A)$ calculated from $T_{o b s}$ and $R_{\text {obs }}$ by $T_{\text {int }}=T_{o b s} /\left(100-R_{o b s}\right)$ and $A=100-T_{o b s}-R_{o b s}$. The inset in (a) shows a photograph of the $a-\mathrm{GaO}_{\mathrm{x}}: \mathrm{H}$ sample.

values extracted from ellipsometry are slightly lower than those determined by PDS, which is attributed to the higher accuracy of the PDS in the UV part of the spectra with respect to the ellipsometry measurements.

The atomic content of $\mathrm{Ga}, \mathrm{O}, \mathrm{C}$, and $\mathrm{H}$ in $a-\mathrm{GaO}_{\mathrm{x}}: \mathrm{H}$ films with $Q_{O}$ of $95 \%$ (400-nm-thick on mirror-polished crystalline Si substrate) was analyzed by RBS and ERDA. An O/Ga ratio of $1.40 \pm 0.10$ was determined by RBS, indicating that the $a-\mathrm{GaO}_{\mathrm{x}}: \mathrm{H}$ films are slightly substoichiometric with respect to $\mathrm{Ga}_{2} \mathrm{O}_{3}$. ERDA measurements indicated a high $\mathrm{H}$ content of $31.7 \pm 3.1$ at. \%, and a $\mathrm{C} / \mathrm{O}$ ratio of $0.167 \pm 0.012$, corresponding to a $\mathrm{C}$ content of $6.0 \pm 0.5$ at. $\%$ homogeneously distributed in the bulk of the film (Fig. C.1. of supplementary material). The presence of $\mathrm{H}$ and $\mathrm{C}$ most likely originates from the use of TMG $\left[\mathrm{Ga}\left(\mathrm{CH}_{3}\right)_{3}\right]$ and $\mathrm{CO}_{2}$ gases.

The microstructure of thick $(50 \mathrm{~nm})$ and thin $(2 \mathrm{~nm}) a$ $\mathrm{GaO}_{\mathrm{x}}: \mathrm{H}$ with a $Q_{\mathrm{O}}$ of $95 \%$ was investigated by STEM imaging and EDX mapping. The $a$-GaOx:H layers were deposited on finished SHJ solar cells in two different configurations: thick $(50 \mathrm{~nm}) a-\mathrm{GaO}_{\mathrm{x}}: \mathrm{H}$ on top of ITO as ARC (Fig. 4) and thin $(2 \mathrm{~nm}) a-\mathrm{GaOx}: \mathrm{H}$ between the $a-\mathrm{Si}: \mathrm{H}$ and the ITO (see Fig. D1 of supplementary material ${ }^{61}$ ), to test whether it could be deposited as an electron transport layer, replacing the doped $a-\mathrm{Si}: \mathrm{H}$ films in traditional SHJ solar cells in a dopant-free architecture. $^{50}$ Figure 4 displays the cross-
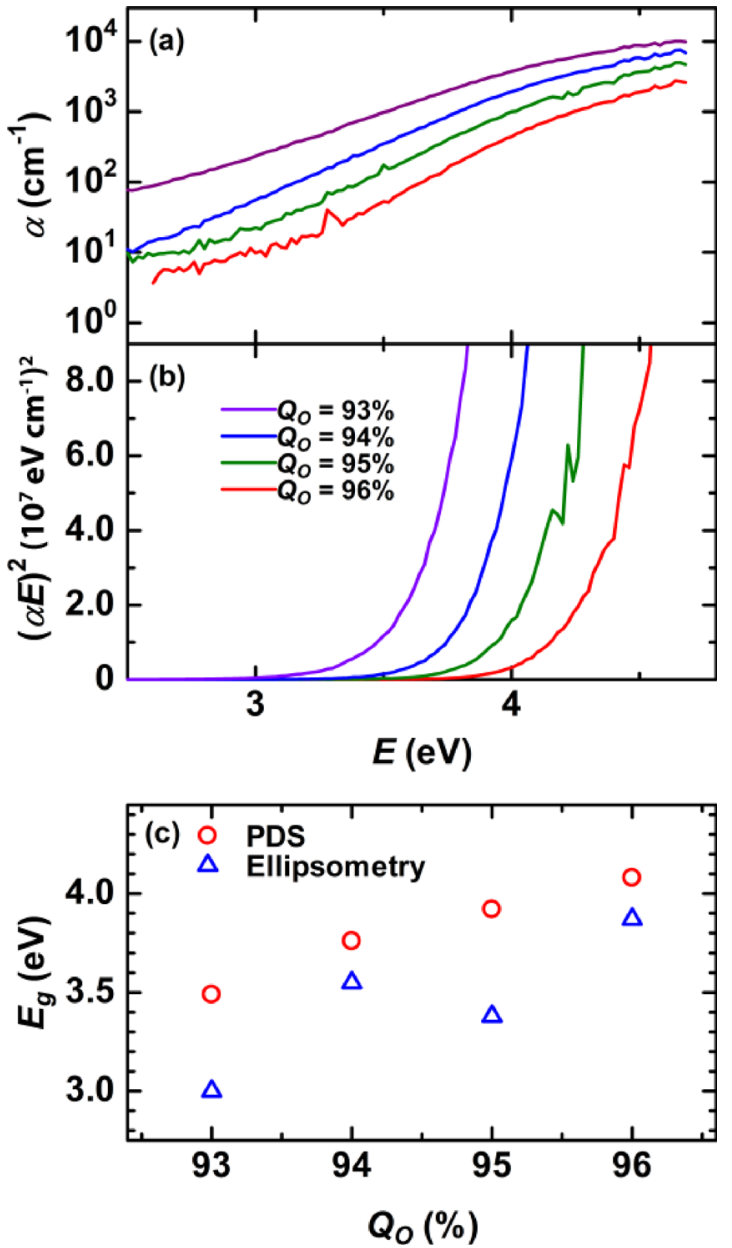

FIG. 2. (Color online) (a) PDS spectra, (b) Tauc plots, and (c) $E_{g}$ values of $a$ $\mathrm{GaO}_{\mathrm{x}}$ : $\mathrm{H}$ thin films with $\mathrm{CO}_{2}$ gas to total flow ratios $\left(Q_{\mathrm{O}}\right)$ of $93 \%, 94 \%$, $95 \%$, and $96 \%$ (thickness of $800 \mathrm{~nm}$, deposited on fused silica substrates).

section TEM and EDX maps of the thick $a-\mathrm{GaO}_{\mathrm{x}}: \mathrm{H}$ deposited on a SHJ cell. Two regions of the pyramid shown in Fig. 4(a) are analyzed in more details; [(c) and (d)] showing one facet of the pyramid and (e) the valley of the pyramid. Both the electron micrograph and elemental distribution EDX maps indicate that the deposition of the $a-\mathrm{GaO}_{\mathrm{x}}: \mathrm{H}$ is mostly conformal. However, while still continuous, the film becomes thinner at the bottom of the valley between the pyramids, presumably due to shadowing effects, or lower adatom surface mobilities. The films are amorphous as shown by the high-resolution TEM micrograph and the Fourier transform shown in Fig. 4(d).

As suggested by the changes in contrast observed in Figs. 4(c) and 4(d), the top view DF image shown in Fig. 5(a) demonstrates the presence of small voids within the $\mathrm{GaO}_{\mathrm{x}}: \mathrm{H}$ film. Indeed, the regions of dark contrast contain voids as neither lighter elements in a solid form (see below) nor crystallites could be detected by EDX [Figs. 5(b) and 5(c)] or highresolution TEM [as in Fig. 4(d)]. Interestingly, the regions with a darker DF contrast observed in Fig. 5(a) exhibit a small peak at $13.5 \mathrm{eV}$ in the EEL spectrum. This small feature is highlighted in Fig. 5(d) by subtracting to the signal integrated in the range $12.5-15 \mathrm{eV}$ a polynomial background 


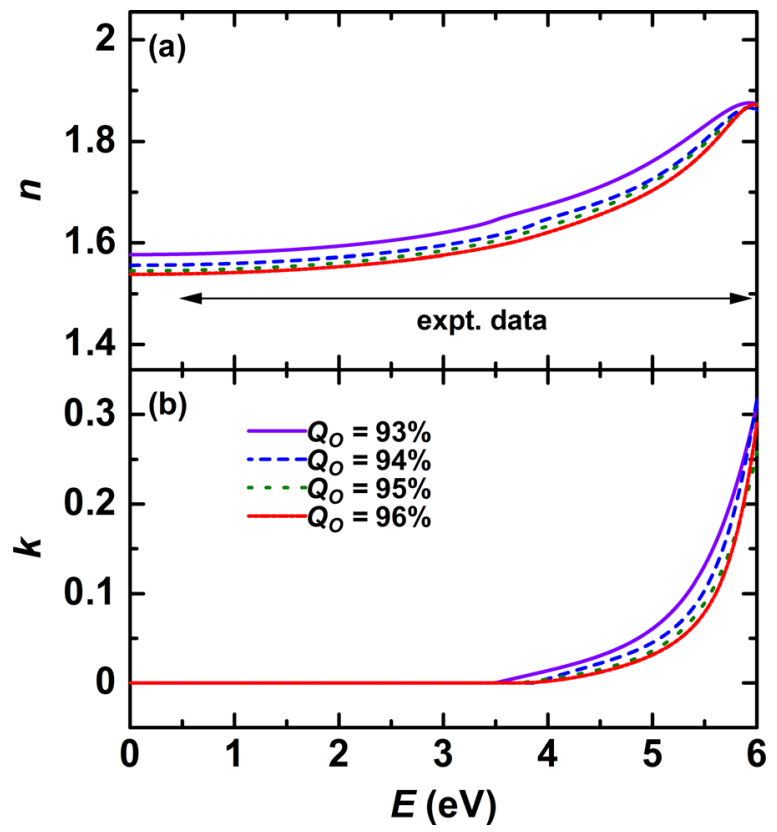

FIG. 3. (Color online) Optical constants of (a) refractive index $n$ and (b) extinction coefficient $k$ derived from the universal dispersion model fits of the ellipsometry measurements of $a-\mathrm{GaO}_{\mathrm{x}}: \mathrm{H}$ thin films grown with a $\mathrm{CO}_{2}$ gas to total flow ratio $\left(Q_{\mathrm{O}}\right)$ of $93 \%, 94 \%, 95 \%$, and $96 \%$, respectively.

fitted in the energy ranges $11-12$ and $15.5-17.5 \mathrm{eV}$. The procedure is illustrated in Fig. 5(e) for the EEL spectra taken at the positions of both a void/less dense region (red square on the left hand side) and a denser region (blue square on the right). Based on a comparison with literature data, ${ }^{51}$ this small peak may correspond to the ionization $\mathrm{K}$ edge of the $\mathrm{H}_{2}$ molecule
$(13.6 \mathrm{eV})$. As demonstrated by the ERDA analysis detailed above, the film contains $31.7 \pm 3.1$ at. $\%$ of $H$. The EELS data hence tend to indicate that it is present in the film in the form $\mathrm{H}_{2}$ trapped in (presumably) closed voids.

AFM was used to measure the surface morphology. Average surface roughness $\left(R_{a}\right)$ and root-mean-square roughness $\left(R_{m s}\right)$ of $a-\mathrm{GaO}_{\mathrm{x}}: \mathrm{H}$ films with $Q_{\mathrm{O}}$ of $93 \%-96 \%$ are shown in Table $\mathrm{I}$ and all below $1 \mathrm{~nm}$, indicating that all films are very smooth.

As previously observed, the $a-\mathrm{GaO}_{\mathrm{x}}: \mathrm{H}$ films presented in this study show lower static $n$ values (1.54-1.58) than $\beta-\mathrm{Ga}_{2} \mathrm{O}_{3}$ (1.89). ${ }^{52}$ We speculate that the low $n$ originates from the presence of nanosize voids as indicated by the TEM data (Figs. 4 and 5). Consistent with this, the results of RBS/ERDA also indicate a lower molecular density $\left(1.3 \times 10^{22} \mathrm{~cm}^{-3}\right)$ compared to the theoretical density of $1.9 \times 10^{22} \mathrm{~cm}^{-3}$ in $\beta-\mathrm{Ga}_{2} \mathrm{O}_{3}$ calculated from the film density of $5.95 \mathrm{~g} \mathrm{~cm}^{-3}$. ${ }^{53}$ To further study the effect of $\mathrm{H}_{2}$, we performed a series of depositions introducing additional $\mathrm{H}_{2}$ during growth. Figure 6 shows $n$ as a function of photon energy for the standard $a-\mathrm{GaO}_{\mathrm{x}}: \mathrm{H}$ films and films grown with 20 and $100 \mathrm{sccm}$ additional $\mathrm{H}_{2}$ flows. A slight refractive index increase (from 1.58 to 1.6 at $2.5 \mathrm{eV}$ ) is observed with increasing $\mathrm{H}_{2}$ flow. As a tentative explanation, the introduction of additional $\mathrm{H}_{2}$ in the plasma may etch the weak bonds at the growth surface of the film, resulting in denser films similarly to $a$-Si:H growth. ${ }^{54}$ These three films were annealed at $200^{\circ} \mathrm{C}$ with no change in optical properties, and then at $500^{\circ} \mathrm{C}$ leading to an $n$ increase of about 0.1 for all samples and a $20-\mathrm{nm}$ thickness decrease. This is attributed to film reorganization, with the disruption of the nanosized voids resulting in a denser film
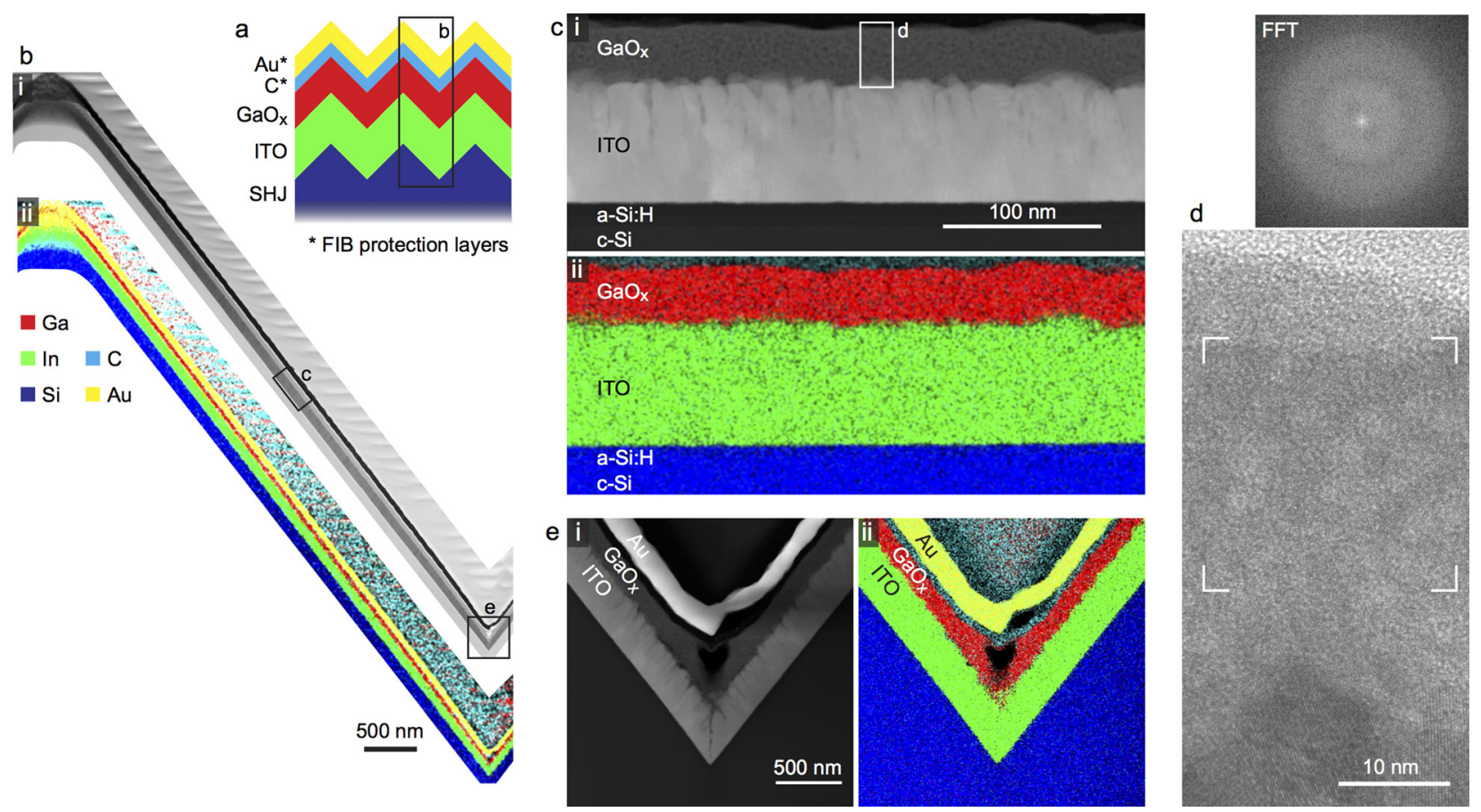

FIg. 4. (Color online) (a) Diagram of the layer stack. (b) STEM HAADF image and EDX map of one Si pyramid. (c)-(e) Higher magnification views of the $\mathrm{GaO}_{\mathrm{x}} / \mathrm{ITO} / \mathrm{a}-\mathrm{Si}: \mathrm{H}$ stacks on [(c) and (d)] the flat side of the pyramid and (e) at the bottom of the pyramid, which show that $a$-GaO $: \mathrm{H}$ is conformal up until reaching the bottom of the valley, where it becomes thinner. The high-resolution TEM image of the $a$-GaOx: $\mathrm{H}_{\text {film }}$ and corresponding Fourier transform shown in (d) confirms the amorphous structure of the film. 

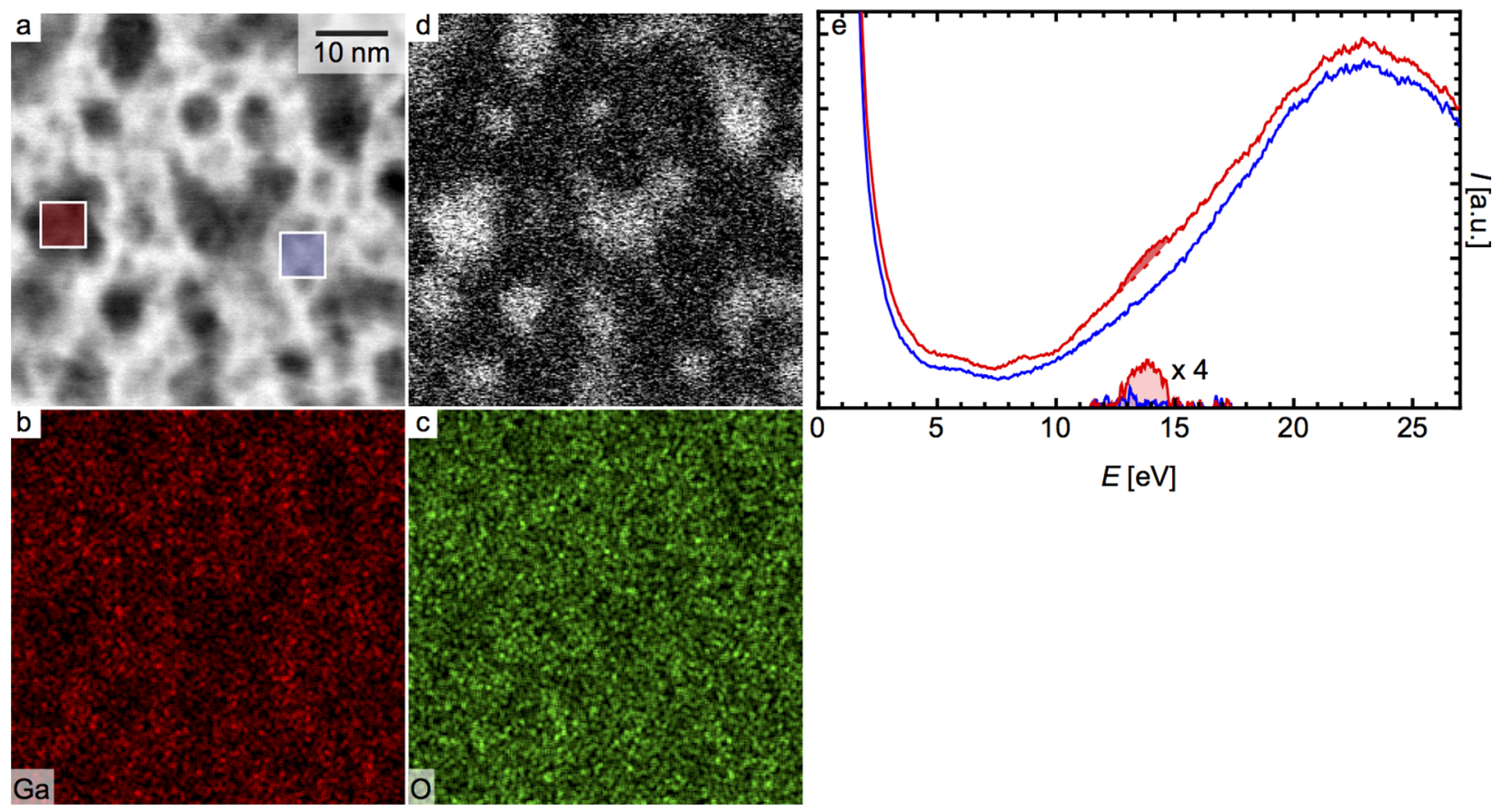

FIG. 5. (a) (Color online) STEM DF micrograph and corresponding EDX mapping of (b) Ga K and (c) O K edges. (d) EEL spectrum image obtained by subtracting a polynomial background to the EEL signal in the range $12-15.5 \mathrm{eV}$ as colored in (e) for the EEL spectra taken either at the position of a void [red square on the left hand side in (a)] or a denser/brighter region (blue square on the right). The background-subtracted signals shown in (e) are magnified four times with respect to the full EEL spectra.

(still amorphous and porous though, based on TEM observations).

A straightforward application of the developed PECVD $a-\mathrm{GaO}_{\mathrm{x}}: \mathrm{H}$ - given the ideal combination of low refractive index ( $n$ of 1.57 at $500 \mathrm{~nm}$ ) and broadband transparency-is its application as a dielectric layer for optoelectronic devices. For example, we investigated the potential of $a-\mathrm{GaO}_{\mathrm{x}}: \mathrm{H}$ as a second ARC layer on the front ITO of SHJ solar cells as shown in Fig. 7(b), similarly to the use of $\mathrm{SiO}_{\mathrm{x}}{ }^{55,56} \mathrm{SHJ}$ solar cells with different ARC architectures were manufactured in CIC. The baseline SHJ cell without a second ARC had a short circuit current density $\left(J_{s c}\right)$ of $39.1 \mathrm{~mA} \mathrm{~cm}^{-2}$, an open circuit voltage of $722 \mathrm{mV}$, a fill factor of $82.2 \%$, and a cell efficiency of $23.2 \%$. The gain in $J_{s c}$ due to the PECVD
$a-\mathrm{GaO}_{\mathrm{x}}: \mathrm{H}$ coating [thickness $(t)$ varied from 40 to $140 \mathrm{~nm}$ ] on the front-side ITO layer $(t=65 \mathrm{~nm})$ is shown in Fig. 7(a). A cell with a thermally evaporated $\mathrm{MgF}_{2}(t=65 \mathrm{~nm}, n$ of 1.37 at $500 \mathrm{~nm})^{57}$ second-layer ARC is also shown as reference. The $65-\mathrm{nm}$-thick $a-\mathrm{GaO}_{\mathrm{x}}: \mathrm{H}$ improves the $J_{s c}$ by $0.47 \mathrm{~mA} \mathrm{~cm}{ }^{-2}(0.27 \%$ efficiency gain in absolute), whereas the 65 -nm-thick layer of $\mathrm{MgF}_{2}$ increases the $J_{s c}$ by $0.57 \mathrm{~mA}$ $\mathrm{cm}^{-2},(0.33 \%$ efficiency gain in absolute). This difference originates from additional reflection in the 400 to $550 \mathrm{~nm}$ wavelength range (external quantum efficiency and reflectance spectra of the three cells shown in supplementary material, Fig. E1) and is due to the less-adequate refractive index of $a-\mathrm{GaO}_{\mathrm{x}}: \mathrm{H}$ compared to that of $\mathrm{MgF}_{2}$ for solar cells measured in air.

TABLE I. Summary of the properties of $a-\mathrm{GaO}_{\mathrm{x}}: \mathrm{H}$ films deposited by PECVD with thicknesses $(t)$ of 100 to $800 \mathrm{~nm}$. The composition of the film grown with $Q_{\mathrm{O}}$ of $95 \%$ is $\mathrm{Ga}_{2} \mathrm{O}_{2.8} \mathrm{C}_{0.46} \mathrm{H}_{2.44}$.

\begin{tabular}{|c|c|c|c|c|}
\hline \multirow[b]{2}{*}{ Parameter } & \multicolumn{4}{|c|}{$Q_{\mathrm{O}}$} \\
\hline & $93 \%$ & $94 \%$ & $95 \%$ & $96 \%$ \\
\hline Phase $(t=400 \mathrm{~nm}$ on glass $)$ & Amorphous & Amorphous & Amorphous & Amorphous \\
\hline Static refractive index $(t=100 \mathrm{~nm}$ on $c-\mathrm{Si})$ & 1.58 & 1.56 & 1.55 & 1.54 \\
\hline Static dielectric constant $(t=100 \mathrm{~nm}$ on $c-\mathrm{Si})$ & 2.49 & 2.42 & 2.39 & 2.37 \\
\hline Bandgap $E_{g}(t=800 \mathrm{~nm}$ on fused silica $)$ & $3.49 \mathrm{eV}$ & $3.76 \mathrm{eV}$ & $3.92 \mathrm{eV}$ & $4.08 \mathrm{eV}$ \\
\hline $\mathrm{O} / \mathrm{Ga}$ ratio $(t=400 \mathrm{~nm}$ on $c-\mathrm{Si})$ & N/A & N/A & $1.40 \pm 0.10$ & N/A \\
\hline $\mathrm{C}$ content $(t=400 \mathrm{~nm}$ on $c-\mathrm{Si})$ & N/A & N/A & $6.0 \pm 0.5$ at. $\%$ & N/A \\
\hline $\mathrm{H}$ content $(t=400 \mathrm{~nm}$ on $c-\mathrm{Si})$ & N/A & N/A & $31.7 \pm 3.1$ at. $\%$ & $\mathrm{~N} / \mathrm{A}$ \\
\hline Molecular density $(t=400 \mathrm{~nm}$ on $c$-Si) & N/A & N/A & $1.38 \times 10^{22} \mathrm{~cm}^{-3}$ & N/A \\
\hline Average surface roughness $R_{a}(t=200 \mathrm{~nm}$ on glass $)$ & $0.350 \mathrm{~nm}$ & $0.652 \mathrm{~nm}$ & $0.588 \mathrm{~nm}$ & $0.510 \mathrm{~nm}$ \\
\hline Root-mean-square roughness $R_{m s}(t=200 \mathrm{~nm}$ on glass $)$ & $0.439 \mathrm{~nm}$ & $0.794 \mathrm{~nm}$ & $0.770 \mathrm{~nm}$ & $0.648 \mathrm{~nm}$ \\
\hline
\end{tabular}




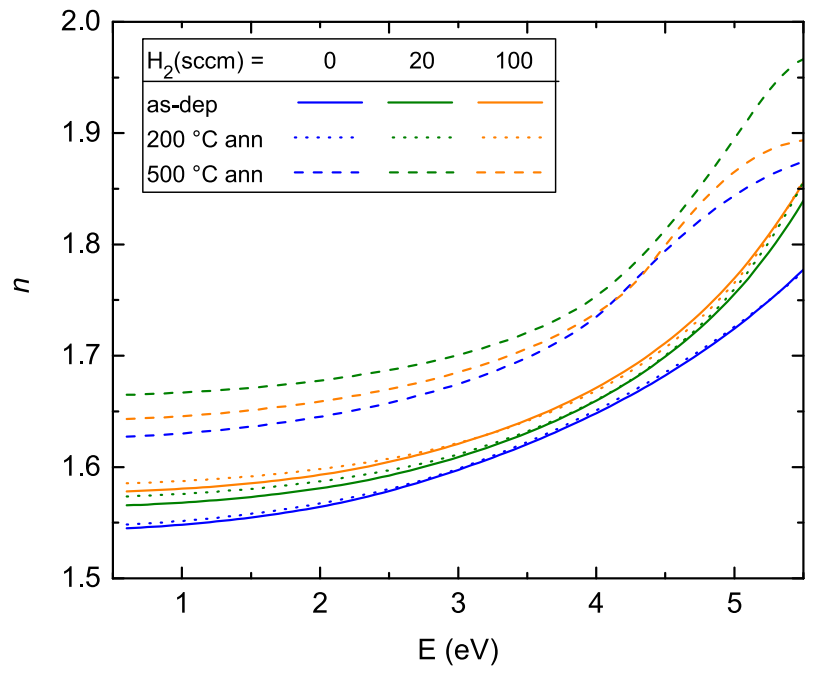

FIG. 6. (Color online) Refractive index (n) of $a-\mathrm{GaO}_{\mathrm{x}}: \mathrm{H}$ films grown with varying $\mathrm{H}_{2}$ flows. $n$ slightly increases with increasing $\mathrm{H}_{2}$ flow, annealing in air at $200{ }^{\circ} \mathrm{C}$ causes no change in $n$, whereas annealing at $500^{\circ} \mathrm{C}$ results in a clear increase of $n$ for all samples.

\section{CONCLUSIONS}

We introduced a PECVD process to deposit $a-\mathrm{GaO}_{\mathrm{x}}: \mathrm{H}$ thin films at low temperature $\left(200^{\circ} \mathrm{C}\right)$ and a detailed analysis of the film properties. The films are hydrogenated, amorphous, dielectric, highly transparent, slightly substoichiometric with respect to $\beta-\mathrm{Ga}_{2} \mathrm{O}_{3}$ and contain carbon, attributed to the use of TMG and $\mathrm{CO}_{2}$ as gallium and oxidant precursors.

\section{(a)}
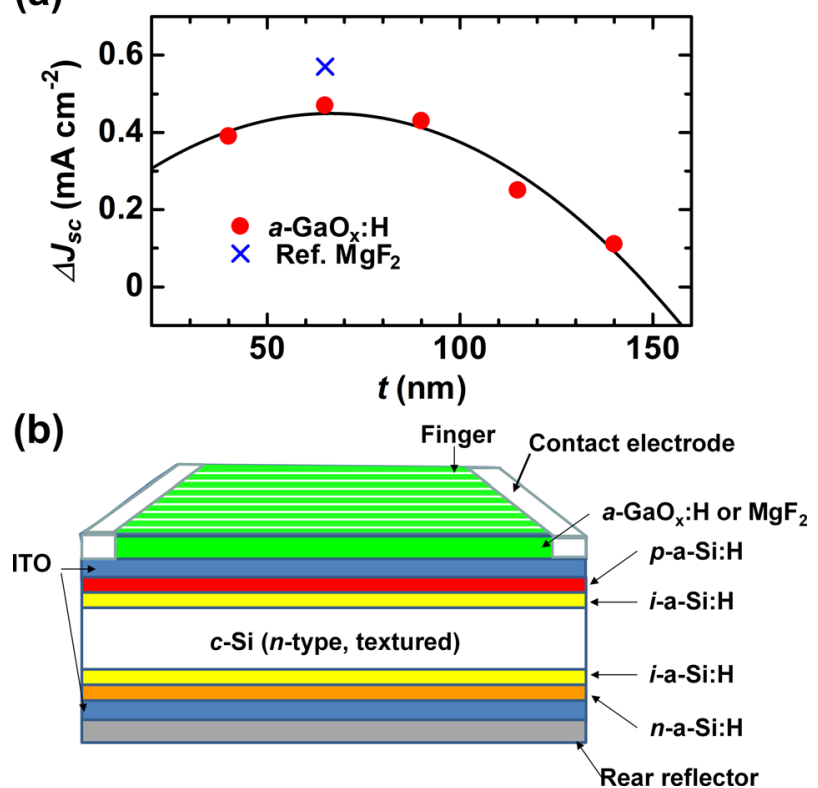

FIG. 7. (Color online) (a) Gain in $J_{s c}$ of a SHJ cell as a function of the thickness of the $a-\mathrm{GaO}_{\mathrm{x}}: \mathrm{H}$ layer used as ARC on the front-side ITO $\left(t_{\mathrm{ITO}}=65 \mathrm{~nm}\right)$. The gain in current when using a thermally evaporated $\mathrm{MgF}_{2}$ ARC is marked by a cross. For each performance analysis, we measured the $J-V$ characteristic of all cells before and after the $a-\mathrm{GaO}_{\mathrm{x}}: \mathrm{H}$ or $\mathrm{MgF}_{2}$ ARC deposition. The solid line is the least-square quadratic fit for the $a-\mathrm{GaO}_{\mathrm{x}}: \mathrm{H}$ cells. (b) Schematic view of the Si heterojunction solar cell structure that employs a second ARC. All finger electrodes and contact electrodes are connected to the front side ITO layer.
A high oxidant content during PECVD was shown to increase the $E_{g}$ up to $4.1 \mathrm{eV}$. Continuous films were obtained down to a thickness of $2 \mathrm{~nm}$. The low refractive index below 1.6 could be linked to nanosized voids, which appear filled with molecular $\mathrm{H}_{2}$. The potential of PECVD a-GaOx:H films as a second layer ARC in SHJ solar cells is demonstrated, and several other applications of PECVD $a-\mathrm{GaO}_{\mathrm{x}}: \mathrm{H}$ may be foreseen. For example, this material may also be used as an electron-transport material for photovoltaics, provided that extrinsic doping [e.g., Sn (Ref. 57) or Si (Ref. 58)] is added to improve the conductivity of the $a-\mathrm{GaO}_{\mathrm{x}}: \mathrm{H}$. Alternatively, $a-\mathrm{GaO}_{\mathrm{x}}: \mathrm{H}$ with a low refractive index can replace $\mathrm{MgF}_{2}$ as the rear reflector in SHJ cells. ${ }^{59,60}$ Finally, the dielectric characteristics of the PECVD layers shown in this study are promising to apply as the dielectric in thin-film transistors. Furthermore, several aspects make PECVD an attractive method for the deposition of metal oxides, notably in the field of solar cells: softness of the deposition, extensive control of doping and stoichiometry, thickness control from nanometer to microns with the tunable deposition rate, and scalability and reliability at the industrial level, and this demonstration of PECVD-grown metal oxide could pave the road to the development of other PECVD metal oxide materials.

\section{ACKNOWLEDGMENTS}

The authors are grateful to Jakub Holovsky for the PDS measurement and Damien Maire for AFM measurements. The authors are also grateful to Stephanie Essig, Evgeny Zamburg, Jan Haschke, Raphaël Monnard, Jean Cattin, Andrea Tomasi, Olivier Dupré, and Philipp Löper for fruitful discussions. This work received financial support from the Swiss Federal Office of Energy, EU FP7 program (CHETAAH Project, Contract No. 609788), CCEM CONNECT PV, Swiss National Science Foundation via the NRP70 "Energy Turnaround project "PV2050" and the "DisCO" (No. CRSII2_154474) projects. The authors thank CIME at EPFL for microscopes access. Daniel Franta acknowledges the financial support from project LO1411 (NPU I) funded by the Ministry of Education Youth and Sports of Czech Republic.

${ }^{1}$ H. H. Tippins, Phys. Rev. 140, A316 (1965).

${ }^{2}$ M. Orita, H. Ohta, M. Hirano, and H. Hosono, Appl. Phys. Lett. 77, 4166 (2000).

${ }^{3}$ T. Onuma, S. Fujioka, and T. Yamaguchi, Appl. Phys. Lett. 103, 041910 (2013).

${ }^{4}$ M. Higashiwaki, K. Sasaki, A. Kuramata, T. Masui, and S. Yamakoshi, Appl. Phys. Lett. 100, 013504 (2012).

${ }^{5}$ N. Ma, N. Tanen, A. Verma, Z. Guo, T. Luo, and H. Xing, Appl. Phys. Lett. 109, 212101 (2016).

${ }^{6}$ K. Irmscher, Z. Galazka, M. Pietsch, R. Uecker, and R. Fornari, J. Appl. Phys. 110, 063720 (2011).

${ }^{7}$ T. Oishi, Y. Koga, K. Harada, and M. Kazu, Appl. Phys. Express 8, 031101 (2015).

${ }^{8}$ M. Higashiwaki, K. Sasaki, T. Kamimura, M. H. Wong, D. Krishnamurthy, A. Kuramata, T. Masui, and S. Yamakoshi, Appl. Phys. Lett. 103, 123511 (2013).

${ }^{9}$ N. Ueda, H. Hosono, R. Waseda, and H. Kawazoe, Appl. Phys. Lett. 70, 3561 (1997).

${ }^{10}$ F. Ren, M. Hong, S. N. G. Chu, M. A. Marcus, M. J. Schurman, A. Baca, S. J. Pearton, and C. R. Abernathy, Appl. Phys. Lett. 73, 3893 (1998). 
${ }^{11}$ K. D. Chabak et al., Appl. Phys. Lett. 109, 213501 (2016).

${ }^{12}$ M. D. Heinemann, J. Berry, G. Teeter, T. Unold, and D. Ginley, Appl. Phys. Lett. 108, 022107 (2016).

${ }^{13}$ T. Koida, Y. Kamikawa-Shimizu, A. Yamada, H. Shibata, and S. Niki, IEEE J. Photovoltaics 5, 956 (2015).

${ }^{14}$ T. Minami, Y. Nishi, and T. Miyata, Appl. Phys. Express 6, 044101 (2013).

${ }^{15}$ T. G. Allen, Y. Wan, and A. Cuevas, IEEE J. Photovoltaics 6, 900 (2016).

${ }^{16}$ E. G. Víllora, K. Shimamura, K. Kitamura, and K. Aoki, Appl. Phys. Lett. 88, 031105 (2006).

${ }^{17}$ K. Sasaki, A. Kuramata, T. Masui, E. G. Villora, K. Shimamura, and S. Yamakoshi, Appl. Phys. Express 5, 035502 (2012).

${ }^{18}$ P. Vogt and O. Bierwagen, Appl. Phys. Lett. 106, 081910 (2015).

${ }^{19}$ M. Valet and D. M. Hoffman, Chem. Mater. 13, 2135 (2001).

${ }^{20}$ R. Binions, C. J. Carmalt, I. P. Parkin, and K. F. E. Pratt, Chem. Mater. 16, 2489 (2004).

${ }^{21}$ H. W. Kim and N. H. Kim, Appl. Phys. A 81, 763 (2005).

${ }^{22}$ C. Y. Huang, R. H. Horng, D. S. Wuu, L. W. Tu, and H. S. Kao, Appl. Phys. Lett. 102, 011119 (2013).

${ }^{23}$ D. Gogova, G. Wagner, M. Baldin, M. Schmidbauer, K. Irmscher, R. Schewski, Z. Galazka, M. Albrecht, and R. Fornari, J. Cryst. Growth 401, 665 (2014).

${ }^{24}$ C. L. Dezelah, J. Niinisto, K. Arstila, L. Niinisto, and C. H. Winter, Chem. Mater. 18, 471 (2006).

${ }^{25}$ D. J. Comstock and J. W. Elam, Chem. Mater. 24, 4011 (2012).

${ }^{26}$ T. G. Allen and A. Cuevas, Appl. Phys. Lett. 105, 031601 (2014).

${ }^{27}$ A. Shah, P. Torres, R. Tscharner, N. Wyrsch, and H. Keppner, Science 285, 692 (1999).

${ }^{28} \mathrm{~K}$. Yoshikawa et al., Nat. Energy 2, 17032 (2017).

${ }^{29}$ D. Adachi, J. L. Hernandez, and K. Yamamoto, Appl. Phys. Lett. 107, 233506 (2015).

${ }^{30}$ K. Masuko et al., IEEE J. Photovoltaics 4, 1433 (2014).

${ }^{31}$ M. Taguchi, A. Yano, S. Tohoda, K. Matsuyama, Y. Nakamura, T. Nishiwaki, K. Fujita, and E. Maruyama, IEEE J. Photovoltaics 4, 96 (2013).

${ }^{32}$ H. Fujiwara and M. Kondo, Appl. Phys. Lett. 90, 013503 (2007).

${ }^{33}$ S. De Wolf and M. Kondo, Appl. Phys. Lett. 90, 042111 (2007).

${ }^{34}$ S. De Wolf, C. Ballif, and M. Kondo, Phys. Rev. B 85, 113302 (2012).

${ }^{35}$ R. A. Street, Adv. Mater. 21, 2007 (2009).

${ }^{36} \mathrm{H}$. Tompkins and E. A. Irene, Handbook of Ellipsometry (William Andrew, New York, 2005), pp. 3-90.

${ }^{37}$ S. De Wolf, J. Holovsky, S. J. Moon, P. Loper, B. Niesen, M. Ledinsky, F. J. Haug, J. H. Yum, and C. Ballif, J. Phys. Chem. Lett. 5, 1035 (2014).

${ }^{38}$ M. Morales-Masis, S. M. De Nicolas, J. Holovsky, S. De Wolf, and C. Ballif, IEEE J. Photovoltaics 5, 1340 (2015).
${ }^{39}$ C. Kottler, M. Dobeli, F. Glaus, and M. Suter, Nucl. Instrum. Methods, B 248, 155 (2006).

${ }^{40}$ S. De Wolf, A. Descoeudres, Z. C. Holman, and C. Ballif, Green 2, 7 (2012).

${ }^{41}$ S. Y. Lien, Thin Solid Films 518, S10 (2010).

${ }^{42}$ M. Balestrieri, D. Pysch, J. P. Becker, M. Hermle, W. Warta, and S. W. Glunz, Sol. Energy Mater. Sol. Cells 95, 2390 (2011).

${ }^{43}$ M. Morales-Masis, S. De Wolf, R. Woods-Robinson, J. W. Ager, and C. Ballif, Adv. Electron. Mater. 3, 1600529 (2017).

${ }^{44}$ E. Kobayashi, S. De Wolf, J. Levrat, G. Christmann, A. Descoeudres, S. Nicolay, and M. Despeisse, Appl. Phys. Lett. 109, 153503 (2016).

${ }^{45}$ P. Campbell, S. R. Wenham, and M. A. Green, Sol. Energy Mater. Sol. Cells 31, 133 (1993).

${ }^{46}$ J. Zhao, A. Wang, P. P. Altermatt, S. R. Wenham, and M. A. Green, Sol. Energy Mater. Sol. Cells 41/42, 87 (1996).

${ }^{47}$ P. Jackson, D. Hariskos, E. Lotter, S. Paetel, R. Wuerz, R. Menner, W. Wischmann, and M. Powalla, Prog. Photovoltaics 19, 894 (2011).

${ }^{48}$ J. I. Pankove, Optical Processes in Semiconductors (Dover Publications, Inc., New York, 1971).

${ }^{49}$ D. Franta, D. Nečas, and I. Ohlídal, Appl. Opt. 54, 9108 (2015).

${ }^{50}$ J. Bullock et al., Nat. Energy 1, 15031 (2016).

${ }^{51}$ C. C. Ahn and O. L. Krivanek, EELS Atlas: A Reference Collection of Electron Energy Loss Spectra Covering All Stable Elements (Gatan, Inc., Warrendale, PA, 1983).

${ }^{52}$ M. Rebien, W. Henrion, M. Hong, and J. P. Mannaerts, Appl. Phys. Lett. 81, 250 (2002).

${ }^{53}$ A. Gyekenyesi and M. Halbig, Ceramic Materials for Energy Applications $I V$ : Ceramic Engineering and Science Proceedings (Wiley, Hoboken, NJ, 2014). Vol. 35, No. 7.

${ }^{54}$ J. H. Koh, Y. H. Lee, H. Fujiwara, and C. R. Wronski, Appl. Phys. Lett. 73, 1526 (1998).

${ }^{55}$ D. Zhang, I. A. Digdaya, R. Santbergen, R. A. C. M. M. van Swaaij, P. Bronsveld, M. Zeman, J. A. M. van Roosmalen, and A. W. Weeber, Sol. Energy Mater. Sol. Cells 117, 132 (2013).

${ }^{56}$ S. Y. Herasimenka, W. J. Dauksher, M. Boccard, and S. Bowden, Sol. Energy Mater. Sol. Cells 158, 98 (2016).

${ }^{57}$ N. Suzuki, S. Ohira, M. Tanaka, T. Sugawara, K. Nakajima, and T. Shishido, Phys. Status Solidi (c) 4, 2310 (2007).

${ }^{58}$ S. Müller, H. von Wenckstern, D. Splith, F. Schmidt, and M. Grundmann, Phys. Status Solidi (a) 211, 34 (2014).

${ }^{59}$ Z. C. Holman, A. Descoeudres, S. De Wolf, and C. Ballif, IEEE J. Photovoltaics 3, 1243 (2013).

${ }^{60}$ A. Dabirian, M. Morales-Masis, F. J. Haug, S. De Wolf, and C. Ballif, IEEE J. Photovoltaics 7, 718 (2017).

${ }^{61}$ See supplementary material at https://doi.org/10.1116/1.5018800 for details of XRD, ERDA, ellipsometry fitting data and STEM analysis. 